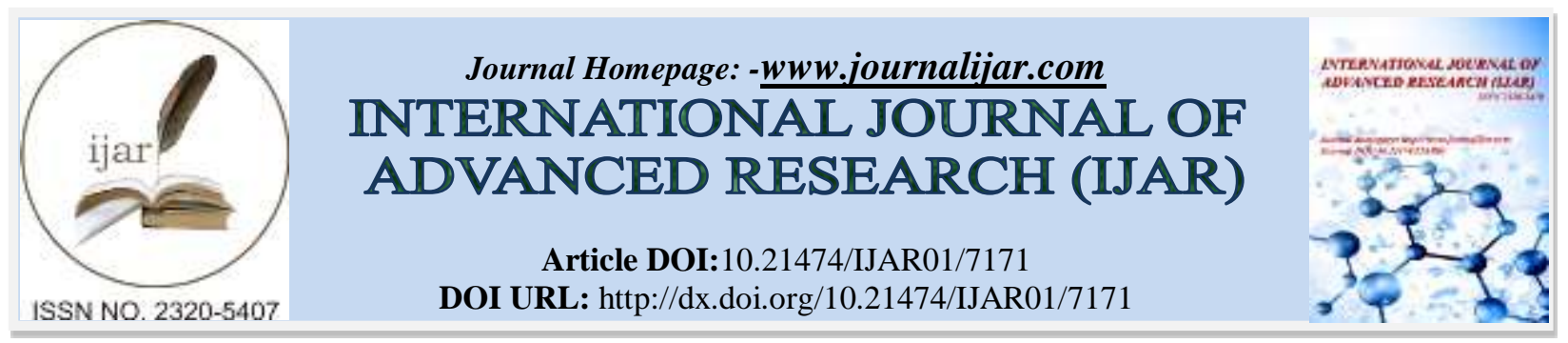

RESEARCH ARTICLE

\title{
A STUDY OF IMPACT OF SEPTOPLASTY ON ALLERGIC RHINITIS IN A TERTIARY CARE CENTERE.
}

Dhinakaran Natarajan, Saravanamuthu Subiah and Raghuram Nataraj.

\section{Manuscript Info}

Abstract

Manuscript History

Received: 22 March 2018

Final Accepted: 24 April 2018

Published: May 2018

\section{Introduction:-}

Difficulty in nasal breathing is probably the most common complaint in rhinological practice. Among the major causes are Deviated nasal septum (DNS) and Allergic rhinitis (AR). Treatment of symptomatic DNS is surgical with high success rate, in terms of patient satisfaction, particularly if the deformity is localised in the caudal septal end or the valve area ${ }^{(1,2)}$. Treatment of AR is a much complex issue, including medication, avoidance of causative allergen, desensitisation and the use of a variety of surgical techniques, which mainly aim at the reduction of the size of the inferior turbinates ${ }^{(3,4)}$.

When deciding on the best therapeutic strategy for patients with nasal pathology one must have a tool for the assessment of subjective symptoms. The Nasal Obstruction Symptom Evaluation(NOSE) Scale is a disease -specific quality of life instrument used for use in nasal obstruction, developed by Stewart et al $l^{(5)}$.

The co-existence of DNS and AR often present a therapeutic challenge for the physician. The aim of this study is to assess the outcome of septoplasty using self- assessment scale and to examine the extent to which this outcome is affected by allergic rhinitis status ${ }^{(6)}$ and to evaluate the effect of septoplasty on the clinical course of allergic rhinitis and improvement in quality of life by comparing Allergic Rhinitis Control Test Questionnaire $(\text { ARCT })^{(7,8)}$.

\section{Aim And Objectives:-}

1. Evaluate the improvement in nasal obstruction following septoplasty in allergic rhinitis patients with associated deviated nasal septum using Nasal Obstruction Symptom Evaluation (NOSE) Scale ${ }^{(6)}$

2. To clarify whether patients with DNS and AR benefit from septoplasty

3. Evaluate the effect of septoplasty on the clinical course of allergic rhinitis and improvement in quality of life by comparing Allergic Rhinitis Control Test Questionnaire (ARCT) ${ }^{(7,8)}$.

\section{Review Of Literature:-}

\section{Deviated Nasal Septum:-}

Deviation of the nasal septum is a common cause of unilateral nasal airway obstruction and may follow nasal and midfacial trauma. Trauma during birth, including forceps placement or passage through a narrow pelvic canal, can cause injury that may lead to early septal deviation or to deviation that is not evident until the more active growth phase of puberty. Minor trauma sustained early in life can be easily overlooked and frequently causes micro 
fractures of the septal cartilage; healing of these micro fractures leads to bending of the cartilage away from the side of injury. When this occurs early in life, it may lead to asymmetric growth of the entire nasal structure as a result of chondrocyte growth interruption. Patients with unilateral septal deviation most often complain of nasal obstruction on the contralateral side, a phenomenon called "paradoxic nasal obstruction" ${ }^{(14)}$. Patients are confused when the physician explains that the nasal passage through which the patient feels airflow moves most freely is actually the smaller of the two sides. Decongesting the nose and then testing airflow through each nostril separately or showing the patient an endoscopic photograph of each passage can help the patient to accept the explanation and understand the true problem.

\section{Aetiology:-}

1. Compression / Birth Trauma ${ }^{(15)}$

2. Developmental error

3. Racial and hereditary factors

\section{Types:-}

1. Anterior dislocation

2. C or S shaped deformity

3. Spurs

4. Thickening (figure 5)
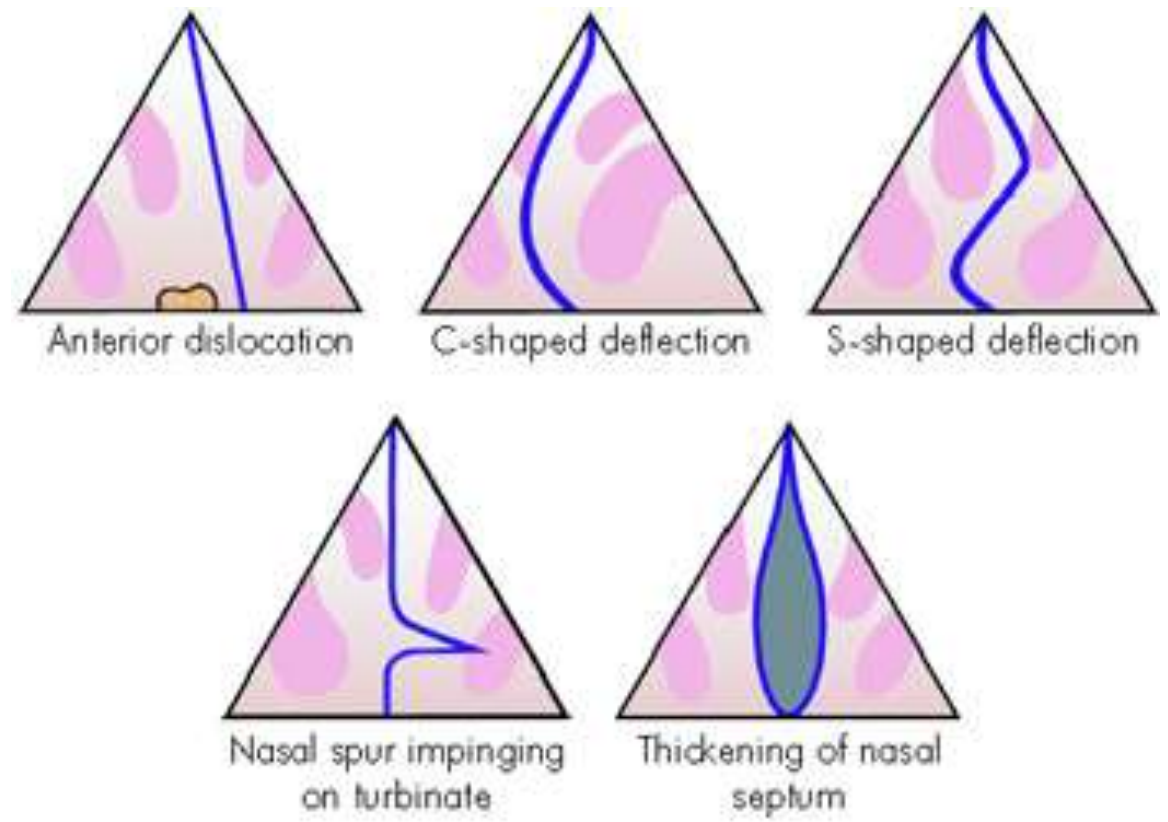

Figure 5:-Types Of Deviated Nasal Septum

\section{Clinical Features:-}

1. Nasal obstruction

2. Headache

3. Sinusitis

4. Epistaxis

5. Anosmia

6. External nasal deformity

7. Middle ear infection

\section{Treatment:-}

1. Submucousal resection

2. Septoplasty 


\section{Measurement Of Obstruction:-}

Acoustic rhinometry, which is an easy test for patients to tolerate and for staff to perform, provides a minimally invasive, convenient, accurate, and expeditious method of measuring dimensions of the nasal airway ${ }^{(1,17,18,19)}$.

The equipment delivers sound waves to the nasal cavity and then measures their reflection (figure 6); the resulting wave is called a rhinogram. The nasal valve causes the first dip in the rhinogram, and the second is caused by the anterior tips of the inferior and middle turbinates (figure 7). Acoustic rhinometric assessment of the valve can be used to determine whether valve surgery may be helpful for the correction of the patients' complaint of nasal airway obstruction.

\section{Adjunctive Tests:-}

A number of adjunctive tests have traditionally been used to confirm the clinical diagnosis of allergic rhinitis. Among these are a differential count of peripheral leukocytes or the examination of smears of nasal secretions for the presence of eosinophils ${ }^{(39)}$. These measures have generally given way to specific diagnostic techniques that measure levels of IgE for various antigens.

The diagnosis of allergic rhinitis is made by history, and the novice rhinologist must realize that the presence of a positive test is just that: a positive test. Clinical correlation between the patient's symptoms and any postulated sensitivity to the incriminated antigens is necessary to confirm a diagnosis of clinically relevant "allergy."

\section{Confirmatory Skin Testing for Allergy:-}

The "gold standard" of allergy testing is generally considered to be skin testing. The basis of this procedure is the reaction between antigen and sensitized mast cells in the skin, producing the classic wheal and flare skin response. This reaction begins with an acute phase that starts within 2 to 5 minutes, reaches a maximum at 10 to 20 minutes, and is characterized by vasodilation (producing erythema) and local edema (producing a wheal). It might be followed by a late phase, with further whealing and induration occurring 4 to 6 hours or more lately.

A number of factors affect skin tests. In addition to the volume and potency of antigen introduced, the degree of sensitization of cutaneous mast cells and reactivity of the skin also are modified by drugs, the age and race of the patient, the area of the body injected, the distance separating individual skin tests, and the time of day of testing ${ }^{(40)}$. Skin test responses are suppressed by antihistamines. All forms of antihistamines must be avoided for at least 48 to 72 hours before skin testing. Although tricyclic antidepressants are no longer commonly used, patients taking them must omit them for up to 96 hours before skin testing, because they suppress whealing responses. Decongestants, systemic steroids, and leukotriene modifiers do not significantly affect skin test results.

Skin tests are generally classified as epicutaneous or intracutaneous. The former group includes scratch tests and prick-puncture testing, and the latter group includes both single-dilution and multiple-dilution intradermal tests.

\section{Confirmatory In Vitro Testing for Allergy:-}

Skin testing for allergy is subject to a number of drawbacks, including the potential for production of a significant reaction and the discomfort, however minimal, associated with the procedure. These drawbacks have led to a continued search for other diagnostic methods. Shortly after the characterization of IgE as the sensitizing factor in allergy, a radioimmunoassay was developed that could detect specific IgE antibodies in serum. This assay, which was called the radioallergosorbent test (RAST), evolved significantly over the years that followed and has become an important tool in the diagnosis of inhalant allergy ${ }^{(41)}$.

Although numerous variations of technology exist, the basic principle of the in vitro analysis of allergen-specific IgE is a "sandwich" technique in which allergens on a solid phase (such as a paper disk) are allowed to react with serum from the patient. Any IgE antibodies to that allergen that are present bind to the solid phase. This resultant complex is then incubated with radiolabeled rabbit antibodies to human IgE. After washing, the amount of radioactivity in the resulting sandwich of allergen/antibody/anti-IgE/radioactive marker on the disk is measured with a gamma counter, and the amount of antibody present is calculated.

Along with the popularization of the allergen-specific RAST, the measurement of total IgE has been advocated as a means of diagnosing the presence of allergy. However, it has become apparent that in some instances a high total $\operatorname{IgE}(>100 \mathrm{IU} / \mathrm{mL})$ is not associated with true allergy, whereas in others a low total $\operatorname{IgE}$ might be present in patients 
with significant allergy. The measurement of total $\operatorname{IgE}$ might be useful in clarifying otherwise equivocal results but has little value when used alone to diagnose the presence of allergy. Modern technology exists for the assay of allergen-specific IgE for numerous antigens. However, as a general rule, an assay of 8 to 15 antigens is sufficient to adequately indicate the presence or absence of significant inhalant allergy ${ }^{(42)}$. Positive responses are followed by additional testing for other relevant antigens.

\section{Materials And Methods:- \\ Study Design:-}

A prospective study with consecutive sampling of all allergic rhinitis patients with symptomatic deviated nasal septum undergoing conventional septoplasty during the study period

\section{Subjects;-}

The study was conducted in a tertiary referral center - Department of otorhinolaryngology, Government Rajaji Hospital, Madurai. All patients of allergic rhinitis with symptomatic deviated nasal septum who underwent septoplasty during the study period. Patients with Deviated nasal septum(DNS) were chosen based on their complaint about difficulty in nasal breathing and diagnosis made based solely on anterior rhinoscopic findings. Diagnostic Nasal endoscopy (DNE) and CT PNS were done in all patients planned for septal surgery.

\section{Anterior Rhinoscopy:-}

Patients with DNS were chosen based on their complaint of difficulty in nasal breathing the diagnosis of DNS was made based on anterior rhinoscopic findings in the outpatient department.

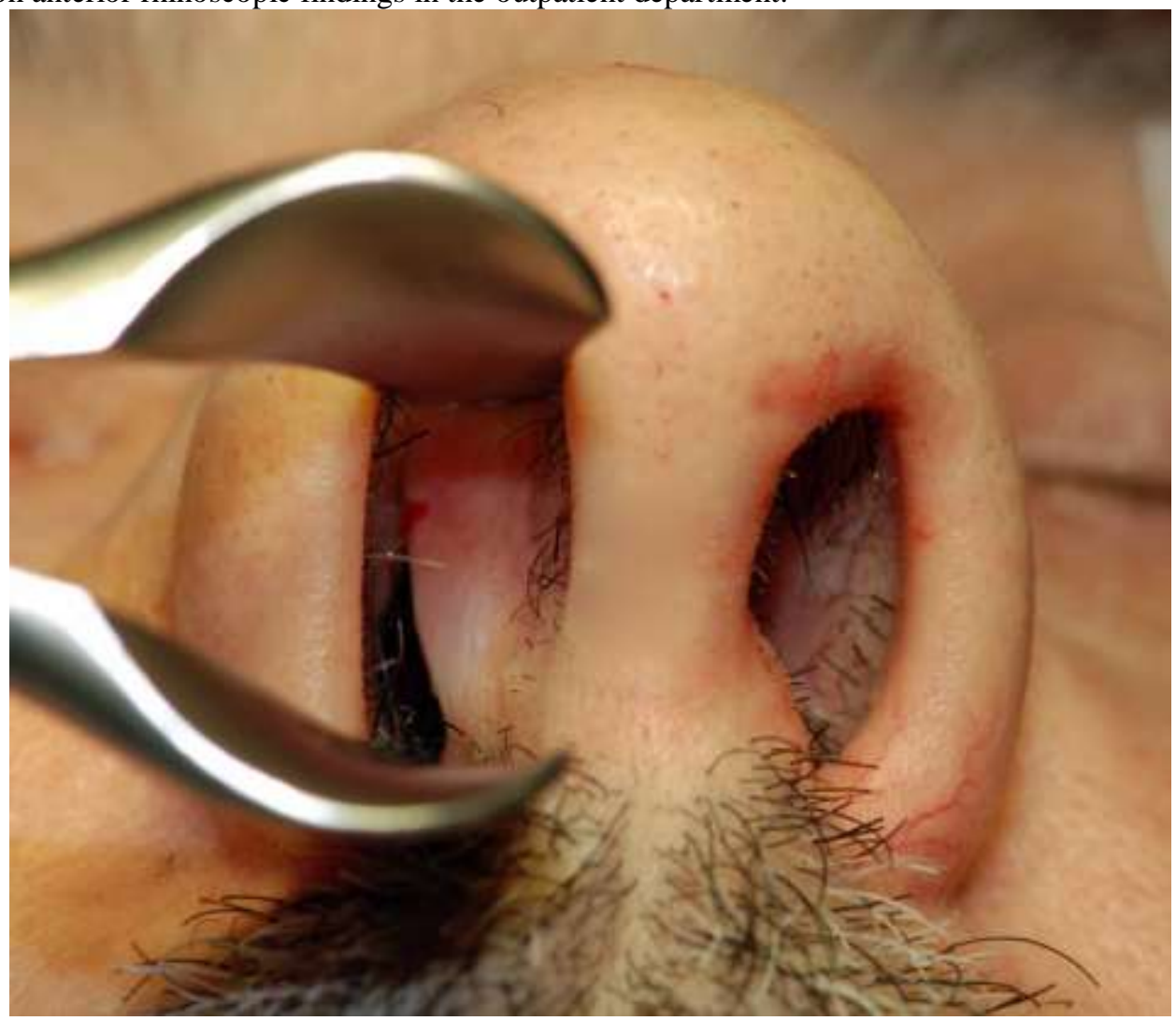

Figure 14:-Anterior Rhinoscopy

\section{Allergic Rhinitis:-}

Clinical diagnosis of allergic rhinitis is based on standard criteria prescribed by Allergic Rhinitis and its Impact on Asthma(ARIA) 2007 guidelines ${ }^{(48,49)}$. Patient allergic rhinitis questionnaire was filled by the subjects and they were categorised into subgroups as intermittent or persistent and mild or moderate - severe based on ARIA guidelines 


\section{Standard criteria:-}

Allergic Rhinitis And its Impact on Asthma (ARIA) guidelines 2007

Symptoms Suggestive Of Allergic Rhinitis:-

1. Watery anterior Rhinorrhoea

2. Sneezing, paroxysmal

3. Nasal obstruction

4. Nasal itching

5. \pm conjunctivitis

Presence of watery anterior rhinorrhoea \pm one or more of the other symptoms $>1$ hour on most days

\section{Classification:-}

\begin{tabular}{|c|c|}
\hline $\begin{array}{l}\text { Intermittent } \\
\text { symptoms } \\
\text { - <4 days per week } \\
\text { - or }<4 \text { weeks }\end{array}$ & $\begin{array}{l}\text { Persistent } \\
\text { symptoms } \\
\text { - }>4 \text { days/week } \\
\text { - and }>4 \text { weeks }\end{array}$ \\
\hline $\begin{array}{l}\text { Mild } \\
\text { all of the following } \\
\text { - normal sleep } \\
\text { - no impairment of daily activities, } \\
\text { sport, leisure } \\
\text { - no impairment of work and school } \\
\text { - no troublesome symptoms }\end{array}$ & $\begin{array}{l}\text { Moderate-Severe } \\
\text { one or more items } \\
\text { - abnormal sleep } \\
\text { - impairment of daily activities, } \\
\text { - imort, leisure } \\
\text { - impaired work and school } \\
\text { - troublesome symptoms }\end{array}$ \\
\hline
\end{tabular}

\section{Diagnostic Nasal Endoscopy:-}

Diagnostic Nasal Endoscopy(DNE) was performed on all subjects using 4mm zero degree Hopkins rod endoscope for a more detailed description and evaluation of the nasal anatomy ${ }^{(50)}$.

Side of maximum deviation, site of maximum deviation based on the five area division by Cottle ${ }^{(51)}$, status of nasal mucousa(normal, pale or congested), turbinates(normal/hypertrophied) are studied

Coexistent pathologies such as sinusitis and polyps are ruled out

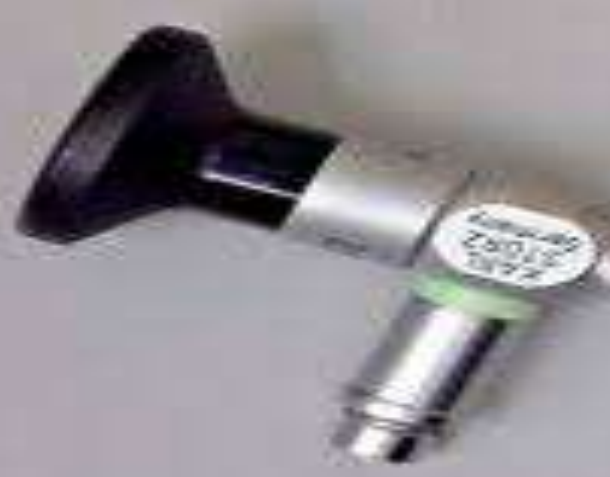

Figure 15:- Zero degree Hopkins rod nasal endoscope 

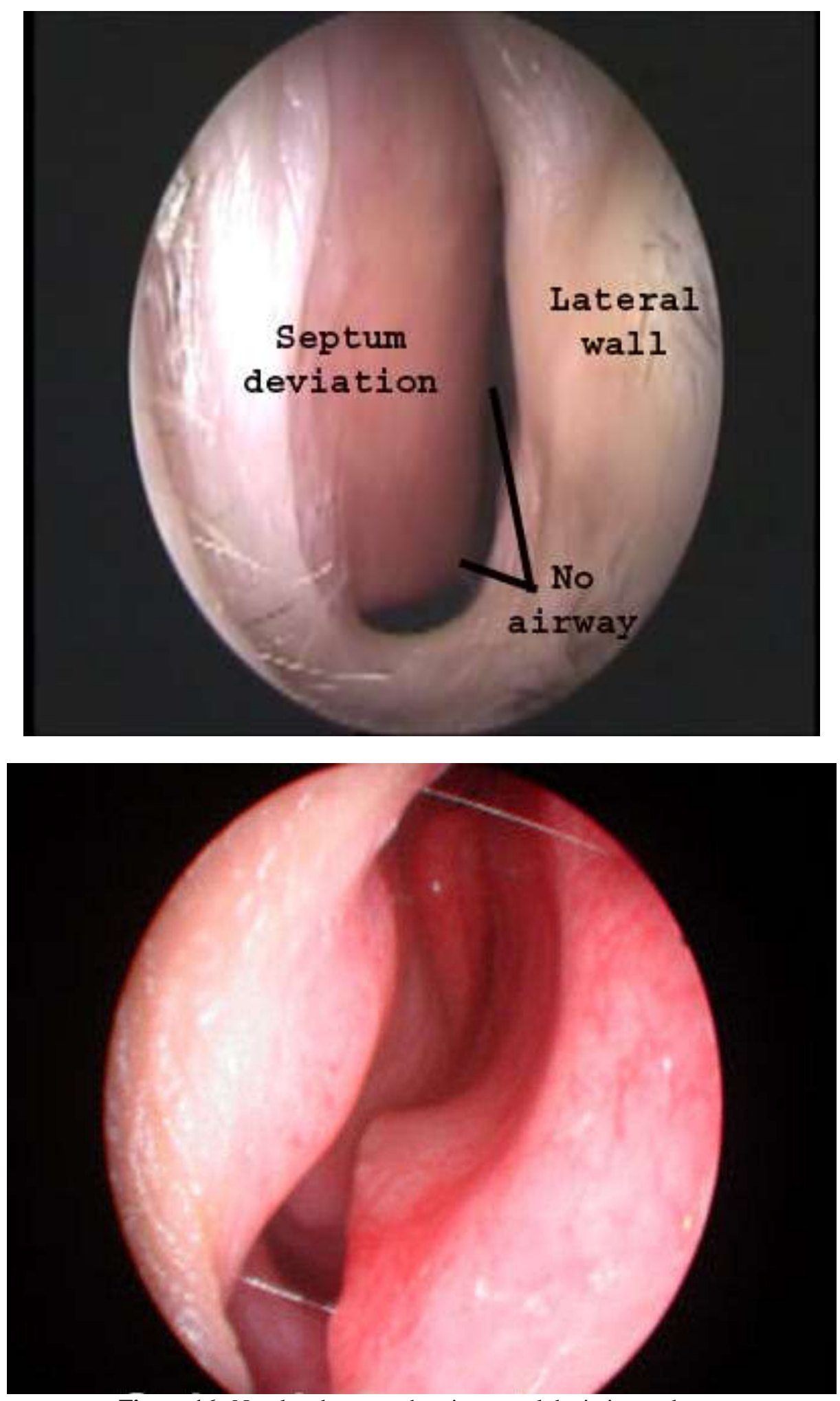

Figure 16:-Nasal endoscopy showing septal deviation and spur

Cottle's Area:-(figure 17)

1. Vestibular area

2. Valvular area 
3. Attical area

4. Medial turbinal area

5. Posterior turbinal/ Choanal area

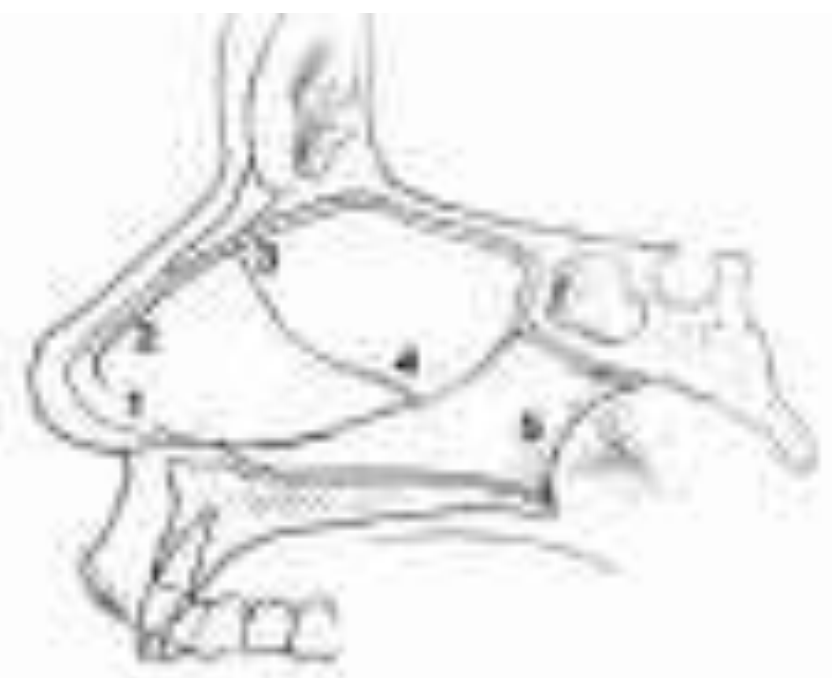

Figure 17:-Cottle's Area

\section{CT PNS:-}

This is done to study the status of paranasal sinuses and to rule out associated sinusitis and polypi. Septal deformities were classified using Mladina classification modified by Janardhan et al. ${ }^{(52,53,54,55)}$ which classifies septal deformities into seven types. In this classification Type I-VI are separate entities while Type VII is combination of Type I-VI 

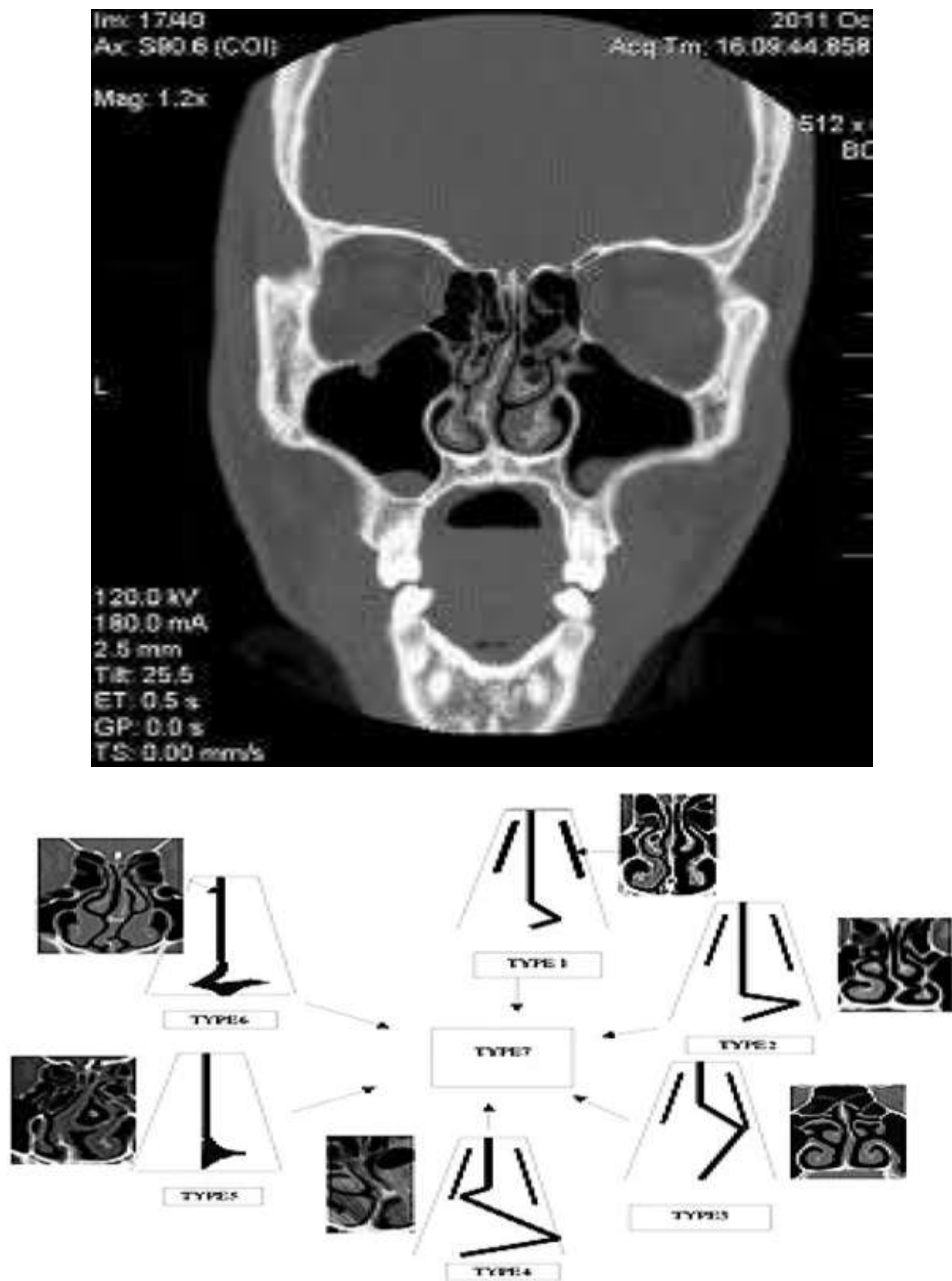

Figure 18:-CT PNS and Mladina classification of septal deviations

Absolute Eosinophil Count:-

Absolute Eosinophil Count is measured in all subjects included in the study using standard venous blood. AEC $\geq 440 / \mathrm{mm}^{3}$ is considered significant ${ }^{(57,58)}$. 


\section{Self Assessment Nose Scale:-}

All participants were assessed the severity of their symptoms based on a Nasal Obstruction Symptom Evaluation (NOSE) Scale prior to and a month following septoplasty ${ }^{(5,54,55,56)}$. Patients were divided into subgroups according to ARIA guidelines of allergic status, comparisions were made.

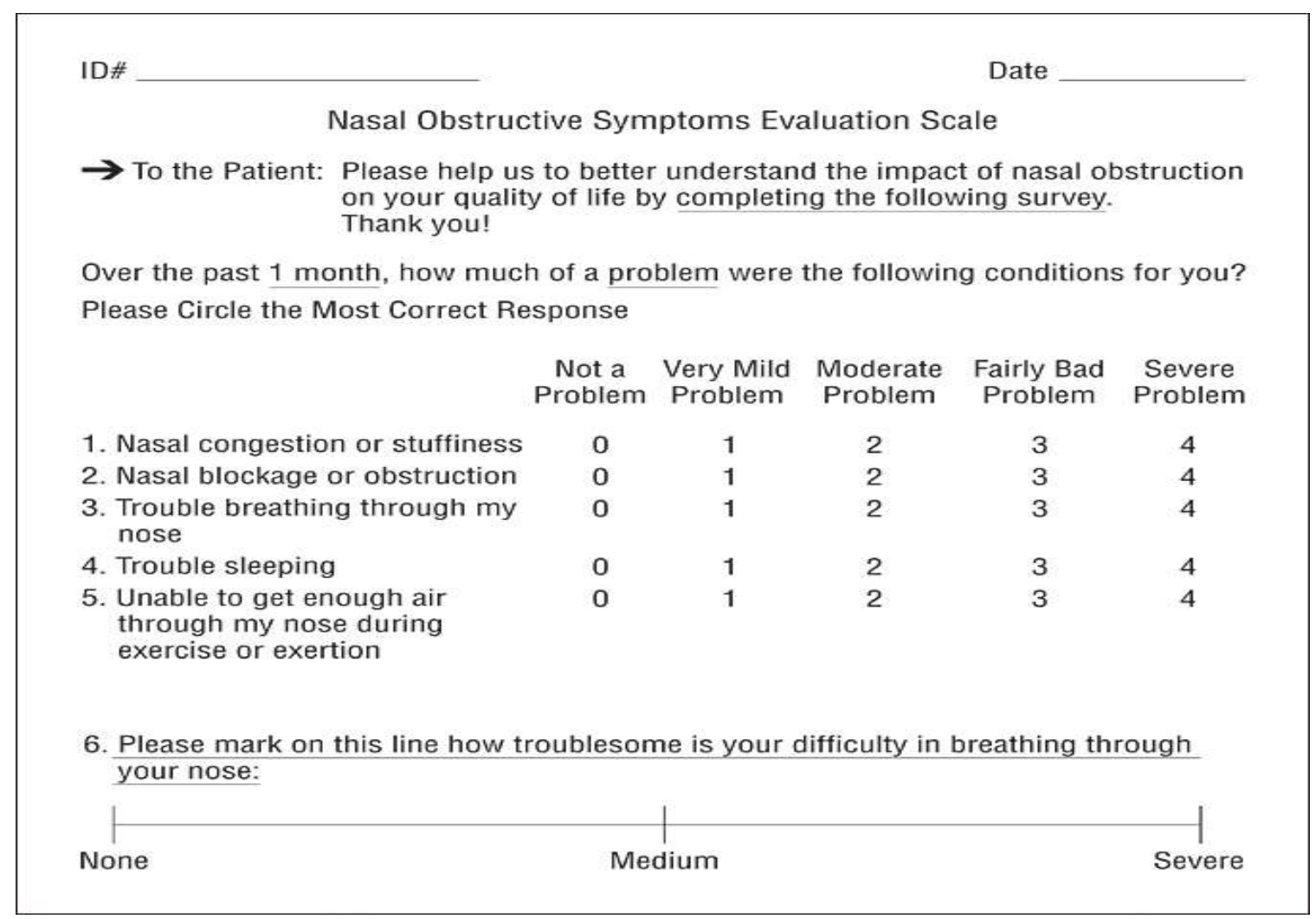

Figure 19:-Nose Scale

\section{Allergic Rhinitis Control Test (Arct) Questionnaire:-}

A five item Allergic Rhinitis Control Test (ARCT) questionnaire ${ }^{(7)}$ was given to allergic patients according to ARIA 2007 guidelines ${ }^{(50,51)}$ who underwent septoplasty prior to surgery and at the end of two months following surgery. Improvement in the allergic status following surgery was evaluated.

\begin{tabular}{|c|c|c|c|c|c|}
\hline \multicolumn{6}{|c|}{ During the last 2 weeks, has your allergic rhinitis had an effect on your professional/personal activities? } \\
\hline Permanently & Very often & Often & Not often & Never & \multirow[t]{2}{*}{ Point } \\
\hline 1 & 2 & 3 & 4 & 5 & \\
\hline \multicolumn{6}{|c|}{ During the last 2 weeks, has your allergic rhinitis made you irritable? } \\
\hline Permanently & Very often & Often & Not often & Never & \multirow[t]{2}{*}{ Points } \\
\hline 1 & 2 & 3 & 4 & 5 & \\
\hline \multicolumn{6}{|c|}{ During the last 2 wedk, has your allergic rhinitis disturbed your sleep (going to sleep, waking at night)? } \\
\hline Permanently & Very often & Often & Not often & Never & \multirow[t]{2}{*}{ Points } \\
\hline 1 & 2 & 3 & 4 & 5 & \\
\hline \multicolumn{6}{|c|}{ During the last $\mathbf{2}$ weels, have you needed to use an additional treatment not prescribed by your doctor to treat your allergic rhinitis? } \\
\hline Four nights or more per week & Two to three nights per week & One night per week & One to two times in all & Never & \multirow[t]{2}{*}{ Points } \\
\hline 1 & 2 & 3 & 4 & 5 & \\
\hline \multicolumn{6}{|c|}{ During the last 2 weeks, how would you assess your allergic rhinitis? } \\
\hline Not controlled at all & Very slightly controlled & Somewhat controlled & Well controlled & Completely controlled & \multirow[t]{2}{*}{ Points } \\
\hline 1 & 2 & 3 & 4 & 5 & \\
\hline Total score & & & & & \\
\hline
\end{tabular}

Figure 20:-ARCT Questionnaire 


\section{Inclusion Criteria:-}

1. Allergic rhinitis patients with symptomatic deviated nasal septum who underwent conventional septoplasty who were willing to take part in the study regardless of age, sex, duration and severity of nasal symptoms

2. Patients who underwent concomitant inferior turbinate volume reduction

3. Patients were included regardless of recent local medication use such as steroid nasal spray, oral antihistaminics for control of nasal allergy

4. Patients were classified into mild or moderate- severe and intermittent or persistent allergic rhinitis according to ARIA 2007

\section{Exclusion Criteria:-}

1. Patients who underwent other forms of septal correction such as SMR

2. Patients who underwent endoscope assisted septal corrections

3. Patients with co-existent sinus pathologies such as sinusitis or polyp or those who underwent septoplasty in addition to any form of endoscopic sinus surgery, antrostomy, Caldwell luc, conchoplasty, rhinoplasty, etc.

4. Patients who underwent septoplasty as a part of another surgical procedure

5. Allergic patients receiving systemic steroids

6. Revision cases were excluded

\section{Statistical Analysis:-}

Univariate comparisons of patient characteristics were made pre and post operatively among allergic rhinitis patients undergoing septoplasty. Continuous variables were compared using the independent samples $t$-test and other tests as appropriate. Methods appropriate for paired data were applied to assess the degree of change in NOSE scores after Septoplasty. Similarly the improvement in ARCT score following septoplasty in allergic rhinitis patients with deviated nasal septum was studied.

\section{Comparision Of Decrease In Nose Score Following Septoplasty:-}

Table 1:-Comparision of NOSE score before and after septoplasty

\begin{tabular}{|ll|l|l|l|l|l|l|}
\hline NOSE score & & Mean Before & Mean After & $\mathrm{N}$ & sd before & sd after & p value \\
\hline Mild Intermittent & 15.7 & 9.6 & 10 & 1.252 & 0.699 & $<0.001^{* *}$ \\
\hline $\begin{array}{l}\text { Moderate- } \\
\text { intermittent }\end{array}$ & Severe & 15.95 & 9.65 & 40 & 1.839 & 0.662 & $<0.001^{* *}$ \\
\hline Mild persistent & 16.1 & 9.55 & 38 & 1.189 & 0.645 & $<0.001^{* *}$ \\
\hline $\begin{array}{l}\text { Moderate- } \\
\text { persistent }\end{array}$ & Severe & 16.3 & 9.42 & 12 & 0.965 & 0.900 & $<0.001^{* *}$ \\
\hline Mean & 16.03 & 9.58 & 100 & & & $<0.001^{* *}$ \\
\hline
\end{tabular}

**Denotes significant at $1 \%$ level 
Chart 1:-Comparision of NOSE score before and after septoplasty

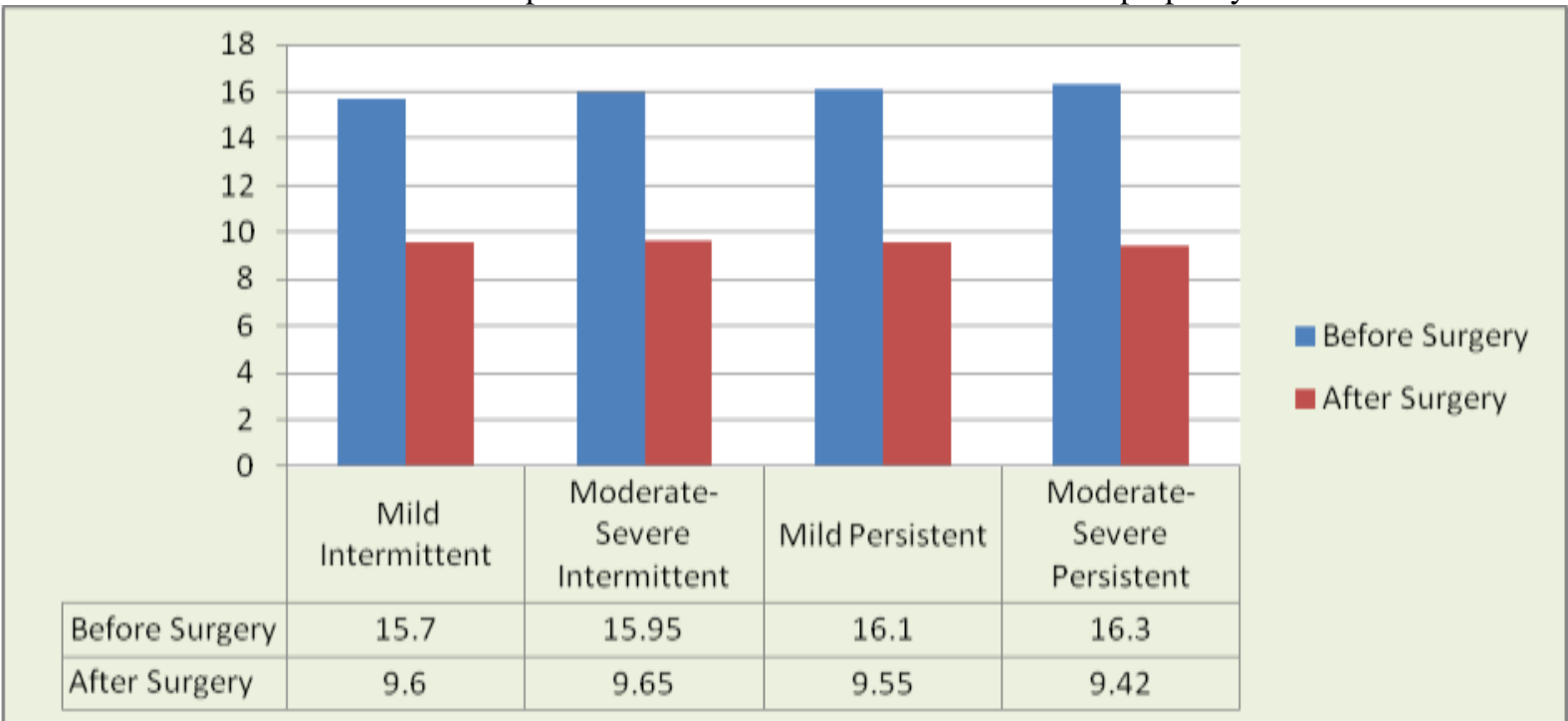

The decrease in NOSE score following septoplasty in each of the four groups is found to be statistically significant $(\mathrm{p}<0.001)$

Table 2:-Comparision of mean decline in NOSE score

\begin{tabular}{|l|l|}
\hline Allergic Groups & Mean decrease in NOSE score following septoplasty \\
\hline Mild Intermittent & 6.1 \\
\hline Moderate-Severe Intermittent & 6.3 \\
\hline Mild Persistent & 6.55 \\
\hline Moderate-Severe Persistent & 6.88 \\
\hline
\end{tabular}

Chart 2:-Comparision of mean decline in NOSE score

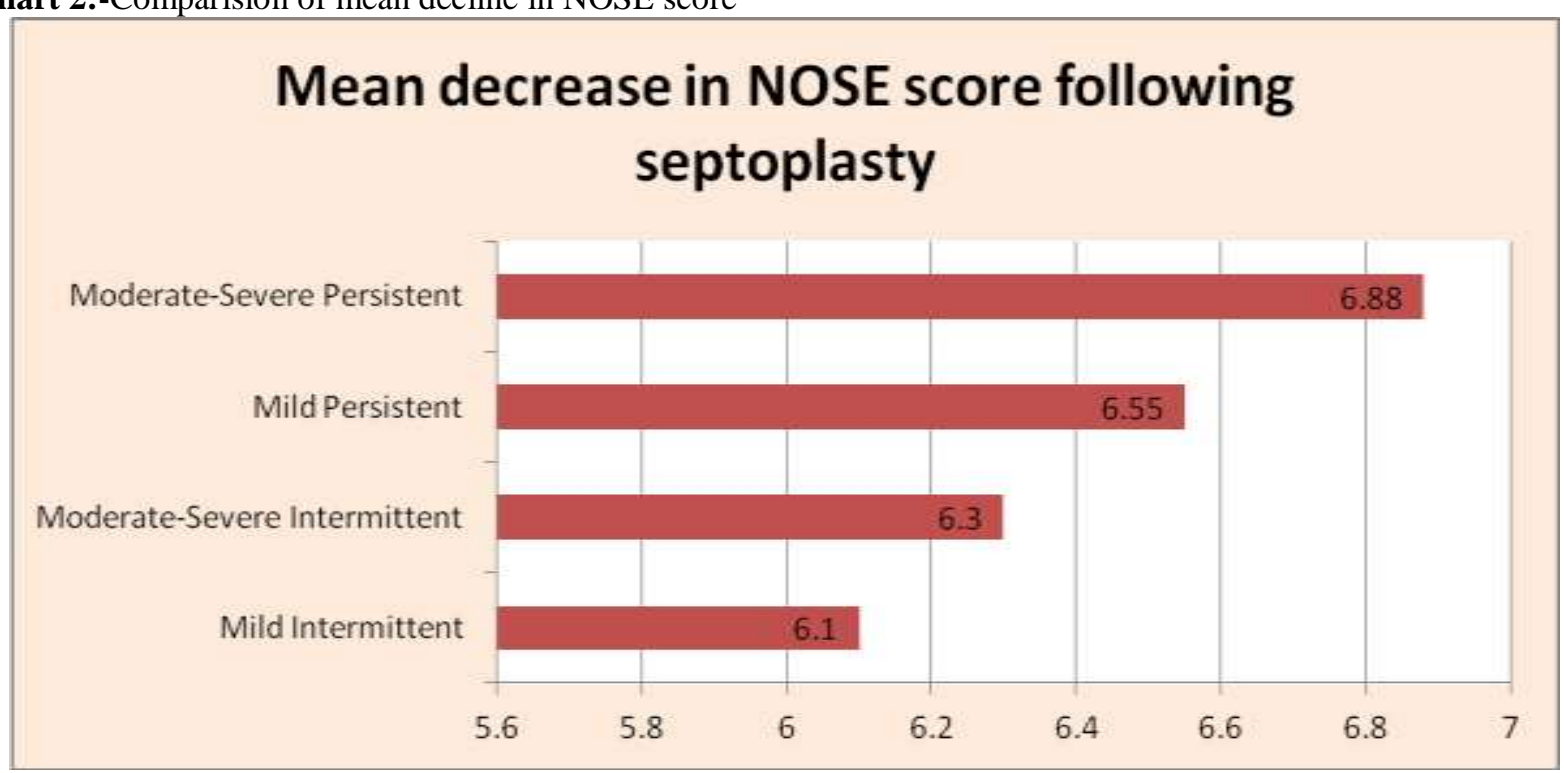

The mean decrease in NOSE score is more than 6 in all the four groups 
Table 3:-ARCT score before and after septoplasty

\begin{tabular}{|c|c|c|c|c|c|c|c|c|c|c|c|c|c|c|c|c|c|}
\hline \multirow[t]{3}{*}{$\begin{array}{l}\text { ARCT } \\
\text { score }\end{array}$} & \multicolumn{4}{|c|}{ Mild Intermittent(10) } & \multicolumn{4}{|c|}{$\begin{array}{l}\text { Moderate-severe } \\
\text { intermittent (40) }\end{array}$} & \multicolumn{4}{|c|}{ Mild Persistent (38) } & \multicolumn{4}{|c|}{$\begin{array}{l}\text { Moderate-severe } \\
\text { persistent (12) }\end{array}$} & \multirow[b]{3}{*}{$\begin{array}{l}\mathrm{p} \\
\text { valu } \\
\mathrm{e}\end{array}$} \\
\hline & \multicolumn{2}{|c|}{ Before } & \multicolumn{2}{|c|}{ After } & \multicolumn{2}{|c|}{ Before } & \multicolumn{2}{|c|}{ After } & \multicolumn{2}{|c|}{ Before } & \multicolumn{2}{|c|}{ After } & \multicolumn{2}{|c|}{ Before } & \multicolumn{2}{|c|}{ After } & \\
\hline & $\begin{array}{l}\text { M } \\
\text { ea } \\
n\end{array}$ & $\begin{array}{l}\mathrm{S} \\
\mathrm{D}\end{array}$ & $\begin{array}{l}\mathrm{M} \\
\text { ea } \\
\mathrm{n}\end{array}$ & SD & $\begin{array}{l}\mathrm{Me} \\
\text { an }\end{array}$ & $\begin{array}{l}\mathrm{S} \\
\mathrm{D}\end{array}$ & $\begin{array}{l}\mathrm{Me} \\
\text { an }\end{array}$ & SD & $\begin{array}{l}\text { Me } \\
\text { an }\end{array}$ & $\begin{array}{l}\mathrm{S} \\
\mathrm{D}\end{array}$ & $\begin{array}{l}\mathrm{Me} \\
\text { an }\end{array}$ & SD & $\begin{array}{l}\mathrm{M} \\
\text { ea } \\
\mathrm{n}\end{array}$ & $\begin{array}{l}\mathrm{S} \\
\mathrm{D}\end{array}$ & $\begin{array}{l}\text { M } \\
\text { ea } \\
n\end{array}$ & SD & \\
\hline $\begin{array}{l}\text { Profes } \\
\text { sional } \\
\text { and } \\
\text { person } \\
\text { al } \\
\text { activit } \\
\text { ies }\end{array}$ & 2.8 & $\begin{array}{l}0.4 \\
22\end{array}$ & 4.4 & $\begin{array}{l}0.51 \\
6\end{array}$ & $\begin{array}{l}2.5 \\
64\end{array}$ & $\begin{array}{l}0.5 \\
02\end{array}$ & $\begin{array}{l}4.1 \\
28\end{array}$ & $\begin{array}{l}0.33 \\
9\end{array}$ & $\begin{array}{l}2.5 \\
26\end{array}$ & $\begin{array}{l}0.5 \\
06\end{array}$ & $\begin{array}{l}4.0 \\
53\end{array}$ & $\begin{array}{l}0.22 \\
6\end{array}$ & $\begin{array}{l}2.4 \\
17\end{array}$ & $\begin{array}{l}0.5 \\
15\end{array}$ & $\begin{array}{l}4.0 \\
83\end{array}$ & $\begin{array}{l}0.28 \\
9\end{array}$ & $\begin{array}{l}< \\
0.00 \\
1^{*}\end{array}$ \\
\hline $\begin{array}{l}\text { Infere } \\
\text { nce on } \\
\text { mood }\end{array}$ & 2.9 & $\begin{array}{l}0.5 \\
68\end{array}$ & 4.6 & $\begin{array}{l}0.51 \\
6\end{array}$ & $\begin{array}{l}2.8 \\
72\end{array}$ & $\begin{array}{l}0.4 \\
09\end{array}$ & $\begin{array}{l}4.3 \\
08\end{array}$ & $\begin{array}{l}0.46 \\
8\end{array}$ & $\begin{array}{l}2.7 \\
89\end{array}$ & $\begin{array}{l}0.4 \\
13\end{array}$ & 4 & 0 & $\begin{array}{l}2.9 \\
17\end{array}$ & $\begin{array}{l}0.2 \\
89\end{array}$ & 4 & 0 & $\begin{array}{l}< \\
0.00 \\
1^{*}\end{array}$ \\
\hline $\begin{array}{l}\text { Distur } \\
\text { bed } \\
\text { sleep }\end{array}$ & 2.9 & $\begin{array}{l}0.3 \\
16\end{array}$ & 4.5 & $\begin{array}{l}0.52 \\
7\end{array}$ & $\begin{array}{l}2.6 \\
41\end{array}$ & $\begin{array}{l}0.4 \\
86\end{array}$ & $\begin{array}{l}4.3 \\
59\end{array}$ & $\begin{array}{l}0.48 \\
6\end{array}$ & $\begin{array}{l}2.5 \\
79\end{array}$ & 0.5 & $\begin{array}{l}4.1 \\
58\end{array}$ & 0.37 & $\begin{array}{l}2.5 \\
83\end{array}$ & $\begin{array}{l}0.5 \\
15\end{array}$ & $\begin{array}{l}4.0 \\
83\end{array}$ & $\begin{array}{l}0.28 \\
9\end{array}$ & $\begin{array}{l}< \\
0.00 \\
1^{*}\end{array}$ \\
\hline $\begin{array}{l}\text { Need } \\
\text { for } \\
\text { additi } \\
\text { onal } \\
\text { treatm } \\
\text { ent } \\
\end{array}$ & 2.7 & $\begin{array}{l}0.6 \\
75\end{array}$ & 4.8 & $\begin{array}{l}0.42 \\
2\end{array}$ & $\begin{array}{l}2.7 \\
69\end{array}$ & $\begin{array}{l}0.4 \\
85\end{array}$ & $\begin{array}{l}4.6 \\
67\end{array}$ & $\begin{array}{l}0.47 \\
8\end{array}$ & $\begin{array}{l}2.7 \\
63\end{array}$ & $\begin{array}{l}0.4 \\
9\end{array}$ & 4.5 & $\begin{array}{l}0.50 \\
7\end{array}$ & $\begin{array}{l}2.9 \\
17\end{array}$ & $\begin{array}{l}0.2 \\
89\end{array}$ & $\begin{array}{l}4.6 \\
67\end{array}$ & $\begin{array}{l}0.49 \\
2\end{array}$ & $\begin{array}{l}< \\
0.00 \\
1^{*}\end{array}$ \\
\hline $\begin{array}{l}\text { Absen } \\
\text { ce of } \\
\text { allergi } \\
\text { c } \\
\text { sympt } \\
\text { oms }\end{array}$ & 2.2 & $\begin{array}{l}0.4 \\
22\end{array}$ & 4 & 0 & $\begin{array}{l}1.9 \\
74\end{array}$ & $\begin{array}{l}0.3 \\
62\end{array}$ & $\begin{array}{l}4.0 \\
26\end{array}$ & 0.16 & $\begin{array}{l}1.8 \\
95\end{array}$ & $\begin{array}{l}0.3 \\
11\end{array}$ & $\begin{array}{l}3.9 \\
47\end{array}$ & $\begin{array}{l}0.22 \\
6\end{array}$ & $\begin{array}{l}1.9 \\
17\end{array}$ & $\begin{array}{l}0.2 \\
89\end{array}$ & $\begin{array}{l}3.9 \\
17\end{array}$ & $\begin{array}{l}0.28 \\
9\end{array}$ & $\begin{array}{l}< \\
0.00 \\
1^{*}\end{array}$ \\
\hline $\begin{array}{l}\text { Total } \\
\text { score }\end{array}$ & $\begin{array}{l}13 . \\
5\end{array}$ & $\begin{array}{l}1.0 \\
8\end{array}$ & $\begin{array}{l}22 . \\
3\end{array}$ & $\begin{array}{l}0.82 \\
3\end{array}$ & $\begin{array}{l}12 . \\
821\end{array}$ & $\begin{array}{l}0.8 \\
85\end{array}$ & $\begin{array}{l}21 . \\
487\end{array}$ & $\begin{array}{l}0.85 \\
4\end{array}$ & $\begin{array}{l}12 . \\
553\end{array}$ & $\begin{array}{l}1.1 \\
08\end{array}$ & $\begin{array}{l}20 . \\
658\end{array}$ & $\begin{array}{l}0.53 \\
4\end{array}$ & $\begin{array}{l}12 . \\
75\end{array}$ & $\begin{array}{l}0.9 \\
65\end{array}$ & $\begin{array}{l}20 . \\
75\end{array}$ & $\begin{array}{l}0.75 \\
4\end{array}$ & \begin{tabular}{|l}
$<$ \\
0.00 \\
$1^{*}$ \\
\end{tabular} \\
\hline & & & & $\begin{array}{l}<0.0 \\
01^{*}\end{array}$ & & & & $\begin{array}{l}<0 . \\
001\end{array}$ & & & & $\begin{array}{l}<0.0 \\
01^{*}\end{array}$ & & & & $\begin{array}{l}<0.0 \\
01^{*}\end{array}$ & \\
\hline
\end{tabular}

* Denotes significant at $1 \%$ level 
Chart 3:-ARCT score before and after septoplasty

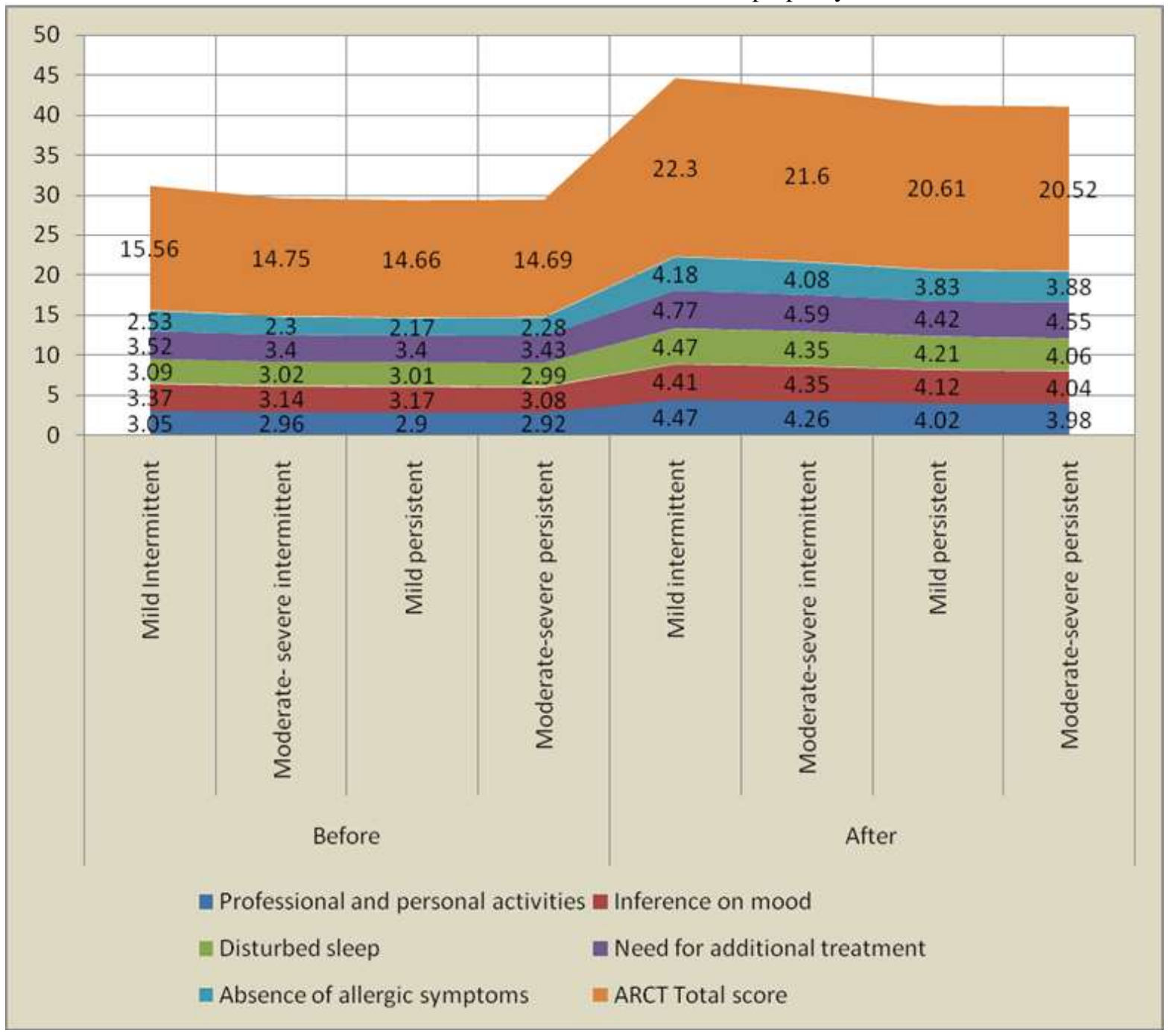

The ARCT score two months following septoplasty has increased to a stastistically significant in each of the four allergic groups showing remarkable control of allergic rhinitis following the procedure

\section{Results:-}

One hundred and eight allergic patients underwent septoplasty during the study period. Follow-up data were obtained from one hundred patients. Eight patients either failed to turn for follow up or developed complications. Therefore complete data were available for 100 subjects. Of the 100 patients studied, 10 patients fell under Mild intermittent group, 40 in Moderate-severe intermittent, 38 in Mild persistent group, 12 under Moderate- persistent group according to the ARIA guidelines. ${ }^{(50,51)}$

Following septoplasty a decrease in NOSE score was observed in all patients except for one which showed an increase. Pre operative NOSE score was distributed as Mild intermittent( mean 15.7, sd 1.252) Moderate-severe intermittent(mean 15.95, sd 1.839 ) Mild persistent( mean 16.1, sd 1.189) Moderate- severe persistent(mean 16.3, sd 0.965 ) and the post operative scores recorded at the end of one month following septoplasty were Mild intermittent (mean 9.6, sd 0.699) Moderate- severe intermittent(mean 9.65, sd 0.662) Mild persistent(mean 9.55, sd 0.645) Moderate- severe persistent(mean 9.42, sd 0.900). The mean decrease in NOSE score following septoplasty was in Mild intermittent(6.1), Moderate-severe intermittent(6.3), Mild persistent(6.55), Moderate- severe persistent(6.88). The mean decrease in NOSE score following septoplasty overall was (pre-operative 16.03, postoperative 9.58, $\mathrm{p}<0.001$ ) analysed to be statistically significant ( significant at $1 \%$ level, $99 \% \mathrm{CI}$ ). This clearly shows that in allergic 
patients with deviated nasal septum, irrespective of the allergic status septoplasty significantly improves the nasal obstruction as shown by the decrease in NOSE score to a statistically significant extent.

ARCT scores were recorded pre operatively and at the end of two months post operatively and results were analysed. Pre operative score was (mean $12.77 \pm$ SD 1.024) and the post operative score ( mean $21.8 \pm$ SD 0.914) with $\mathrm{p}$ value $<0.001$, significant statistically at $1 \%$ level, $99 \%$ CI. This clearly shows that in allergic rhinitis patients with symptomatic deviated nasal septum, septoplasty improves the quality of life pertaining to allergy to a statistically significant extent.

\section{Discussion:-}

Based on the prementioned data from subjective measurements, a conclusion with major impact on patient management is reached. Coexistence of allergic rhinitis with nasal septum deviation seems to place patients in a less favourable prognostic group as far as surgical outcome and patient satisfaction are concerned. This conclusion is similar to the usual, undocumented, clinical observation that patients without allergic rhinitis undergoing septoplasty tend to be more satisfied post-operatively. Other authors such as Stewart et al. ${ }^{(5)}$ have found that patient satisfaction following septoplasty did not correlate with their allergic rhinitis. Bohlin et al ${ }^{(59)}$ have shown that after proper patient selection, based on active rhinomanometry and anterior rhinoscopy, $84 \%$ of the patients were satisfied 10 years post-operatively, while the decrease in nasal resistance after the operation remained the same after 10 years ${ }^{(60)}$.

The most common complaint in rhinologic practice is difficulty in nasal breathing, and nasal septal deviation and allergic rhinitis are among the common causes. ${ }^{(61)}$ The clinician often faces therapeutic dilemmas when managing a patient who suffers from both these entities. In such cases, when the deviated septum completely obstructs the nasal chamber the answer is obvious. When the deformity is less pronounced, on the other hand, the therapeutic decision is more complex. Unfortunately history and physical examination, although imperative, are usually not sufficient to provide a definite answer. ${ }^{(\mathbf{6 2})}$

In general, available diagnostic tools can be categorized as subjective, including patient history, the Nasal Obstruction Evaluation Scale (NOSE) ${ }^{(63)}$, questionnaires incorporating a visual analogue scale ${ }^{(64)}$, the Fairly nasal symptom score, the Nottingham health profile and the General health questionnaire ${ }^{(65,66)}$, and objective, such as rhinomannomertry, acoustic rhinometry ${ }^{(67)}$, computed tomography and peak inspiratory nasal flow ${ }^{(68)}$.

In the present study, in order to assess subjective symptoms we employed the Nasal Obstruction Symptom Evaluation (NOSE) Scale, which is a disease-specific quality of life instrument for use in nasal obstruction, developed by Stewart et $\mathrm{al}^{(63)}$. Its major advantage is that it is superior to history in evaluating the subjective symptoms in the most accurate possible way with regard to difficulty in breathing, whereas other scales, such as the Fairley nasal symptom score, are not equally reliable ${ }^{(64)}$. For objective assessment of nasal patency, methods such as active anterior rhinomanometry, posterior rhinomanometry or passive rhinomanometry are used by a number of investigators to document the pre to post -operative reduction in mean airway resistance values in patients who underwent septoplasty ${ }^{(69,70,71,72)}$. However examinations such as rhinomanometry, acoustic rhinometty or peak inspiratory nasal airflow have not been incorporated into our study, because of non-availability.

The best management of patients with nasal septal deviation is still under debate. There are no evidencebased guidelines for which patients to operate on and which patients will benefit the most. Treatment of choice for nasal septal deviation is septoplasty, although other surgical techniques, such as submucous resection, have been used with less favourable results ${ }^{(73)}$. Septoplasty is one of the most frequently performed surgical procedures in otorhinolaryngology and its selection relies largely on clinical judgement alone. Practice based on experience alone is not regarded satisfactory neither from a scientific nor from a legal point of view. A significant number of patients report to be less satisfied following surgery, thus providing proof of the limitations of clinical selection criteria ${ }^{(74)}$. The initial improvement of nasal ventilation felt in the first months or years after surgery is progressively devaluated by the patients with the passing of time, particularly if other causes for nasal obstruction, such as chronic rhinitis and rhinosinusitis, also coexist ${ }^{(75)}$. On the other hand, some investigators believe that, regardless of the magnitude of septal deviation, most patients benefit from its surgical correction because it eliminates a 
possible contributing factor to the pathogenesis of chronic rhinosinusitis ${ }^{(76)}$. Nevertheless, inappropriate selection of surgery as a therapeutic option and inappropriate choice of surgical modality do seem to be major causes for dissatisfaction ${ }^{(77)}$.

Allergic rhinitis(AR) significantly reduces quality of life (QOL), interferes with both attendance and performance at school and work ${ }^{(\mathbf{7 8 , 7 9 )}}$ and results in substantial financial costs ${ }^{(\mathbf{8 0})}$. AR is common and affects

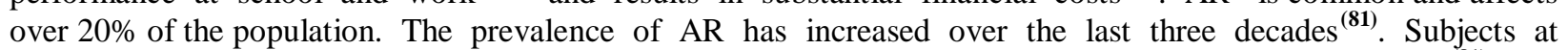
most risk are those with atopy, with a family history of rhinitis, first-born children and immigrants ${ }^{\text {(81) }}$. AR is the predominant form in children, but accounts for about a third of rhinitis in adults. Treatment of allergic rhinitis consists of patient education, allergen avoidance, pharmacotherapy, immunotherapy and surgery. The latter mainly aims at the reduction of the inferior turbinates ${ }^{(1,3)}$.

The statistically significant decrease in NOSE score in the allergic rhinitis patients with symptomatic deviated nasal septum proves that septoplasty is to be strongly considered an option in case of symptomatic deviated nasal septum even in the presence of allergic rhinitis. as found in the present study, in contrast with clinical experience that has been previously documented ${ }^{(\mathbf{8 2})}$ which may be attributed to the fact that regardless of the final surgical outcome, patients with allergic rhinitis may exhibit more crusting, swelling and discomfort during the early post-operative period or may need additional medication to control their allergy. Another feasible explanation would be the wrong attribution of symptoms by the clinician to the deviated septum pre-operatively when in fact these symptoms are more related to allergic status.

The study also clearly brings out the fact that septoplasty when performed in allergic rhinitis patients with deviated nasal septum improves the allergic rhinitis status. Based on previous studies by Kim YH et al. ${ }^{(8)}$ which employed rhinasthma score to evaluate the improvement in allergic rhinitis by doing only turbinoplasty in one group and septoplasty with turbinoplasty in the other group shows that septoplasty when combined with turbinoplasty is more effective in relieving the allergic status. Sixty-two patients who had undergone septoplasty and turbinoplasty for septal deviation and allergic rhinitis were enrolled in group A. Twenty-six patients who had undergone only turbinoplasty for allergic rhinitis were enrolled in group B. The VAS score, the Average Rescue Medication Score (ARMS), and the Rhinasthma Questionnaire for the quality of life were all obtained from each patient. These parameters were compared before and after the surgery and between the groups. Both groups showed significant improvement of the VAS score $(\mathrm{P}<.001)$. When the change of VAS was compared between groups, there was a significant difference in group A only for nasal obstruction $(\mathrm{P}=.047)$. Comparison of the ARMS between groups showed significant improvement in both groups after the surgery $(\mathrm{P}<.01)$. However, there were no differences between the groups. The Rhinasthma score of group A was significantly lowered after the surgery $(56.4 \pm 13.2$ to $34.1 \pm 12.3, \mathrm{P}<.001)$. The Rhinasthma score of group A was significantly lower than that of group B after the surgery $(\mathrm{P}=.004)$.

In our study we employed the allergic rhinitis control test questionnaire developed by Demoly $\mathrm{P}$ et al. ${ }^{(7)}$ for evaluating the control of allergic rhinitis following septoplasty. The self-assessment score for allergic rhinitis control appeared to be sensitive to change and correlated to the clinical expression of rhinitis and also to its involvement with treatment. These results suggest that this self-completion questionnaire could be used in daily practice at each consultation to determine, in a standardized manner, the level of control of the allergic rhinitis of an individual patient. P value $<0.0001 .{ }^{(7)}$ Our study results clearly shows that in allergic rhinitis patients with symptomatic deviated nasal septum, septoplasty improves the quality of life pertaining to allergy to a statistically significant extent with $\mathrm{p}$ value $<0.001$.

\section{Limitations:-}

A major limitation of this study is that it is a short study with one year study period and a limited follow up of two months following surgery. The evaluation of NOSE score to assess the improvement in nasal obstruction following septoplasty is done at the end of four weeks post operatively and compared with the pre operative score for results may account in both ways. First, since it is the early post-operative period and healing of the surgical wound is still under way, patients may have scored better in the NOSE questionnaire if they were examined after a longer period. On the other hand, the post operative time of four weeks is generally considered enough to judge the surgical outcome and longer periods of follow-up have not shown significant differences in patient satisfaction ${ }^{\mathbf{8 3})}$. Another weakness of the study is that it is purely based on subjective parameter 
(NOSE Scale), and objective methods or other diagnostic tools such as rhinomanometry, acoustic rhinometry or peak inspiratory nasal flow measurement is not employed.

Similarly, the allergic rhinitis control test questionnaire (ARCT) is evaluated at the end of two months following surgery and compared with pre operative score with the improvement in the score following surgery being taken as the effect of septoplasty on allergic rhinitis. This study definitely shows that septoplasty when done in indicated cases with allergic rhinitis clearly has a positive impact, with statistically significant improvement in allergic rhinitis status two months following surgery. However a long term follow-up is necessary to throw more light on the control of allergic rhinitis and improvement in the quality of life following septoplasty.

\section{Conclusion:-}

Based on the prementioned data from subjective measurements, a conclusion with major impact on patient management is reached. It is said in many studies that coexistence of allergic rhinitis with nasal septum deviation seems to place patients in a less favourable prognostic group as far as surgical outcome and patient satisfaction are concerned. Several undocumented clinical observations show that patients without allergic rhinitis undergoing septoplasty tend to be more satisfied post-operatively. Other authors such as Stewart et al. ${ }^{(\mathbf{5 , 6 3})}$ have found that patient satisfaction following septoplasty did not correlate with their allergic rhinitis. Bohlin et al (70) have shown that after proper patient selection, based on active rhinomanometry and anterior rhinoscopy, $84 \%$ of the patients were satisfied 10 years post-operatively, while the decrease in nasal resistance after the operation remained the same after 10 years ${ }^{(84)}$. The present study suggests that in allergic rhinitis patients with symptomatic deviated nasal septum or in other words septoplasty performed in allergic rhinitis with coexistent deviated nasal septum not only improves the nasal obstruction significantly, but also there is a remarkable improvement in the control of allergic rhinitis following surgery.

\section{Recommendations:-}

1. The study undeniably shows that septoplasty when done in allergic patients with symptomatic deviated nasal septum in contrary to the popular belief, results in a significant improvement in nasal obstruction.

2. The study also brings to light that in allergic patients with coexistent deviated nasal septum undergoing septoplasty, there is a remarkable control in allergic status following surgery with signifiacant reduction in the usage of anti allergic medications as well as improvement in the quality of life .

3. Adequate medical management of allergic rhinitis should be the first priority for these cases to obtain maximum results.

4. Treatment for allergic rhinitis should be continued following the correction of nasal septal deviation for satisfactory outcome.

5. Further studies are necessary to validate the long term control of quality of life and of symptoms of allergic rhinitis following surgery. 


\section{References:-}

1. Jalowayski AA, Yuh YS, Koziol JA, Davidson TM. Surgery for nasal obstruction-evaluation by rhinomanometry. Laryngoscope. 1983; 93: 341-345.

2. Velegrakis GA, Papadakis CE, Volitakis M, Nikolidakis A, Naoumidi I, Prokopakis E, Helidonis E. In vitro ear cartilage surgery with carbon dioxide laser: an experimental study. Ann Otol Rhinol Laryngol. 2000; 109: 11621166.

3. Fradis M, Malatskey S, Magamsa I, Golz A. Effect of submucosal diathermy in chronic nasal obstruction due to turbinate enlargement. Am J Otolaryngol. 2002; 23: 332-336.

4. Ding H, Liu J Wang T, Xia G, Liu W. Combination application of radiofrequency ablation in nasal operation. Lin Chuang Er Bi Yan Ke Za Zhi. 2005; 19: 918-919.

6. Stewart MG, Smith TL, Weaver EM, Witsell DL, Yueh B, Hannley MT, Johnson JT. Outcomes after nasal septoplasty: results from the Nasal Obstruction Septoplasty Effectiveness (NOSE) study. Otolaryngol Head Neck Surg. 2004; 130: 283-290.

7. Chetan Ghorpade, Raghuji D Thorat, Vasanti Patil.Efficacy of performing septoplasty in allergic rhinitis. MedPulse- International medical journal. March 2016;3(3):288-291.

8. Demoly P, Jankowski R, Chassany O, Bessah Y, Allaert FA. Validation of a self-questionnaire for assessing the control of allergic rhinitis. Clinical \& Experimental Allergy. 2011 Jun 1;41(6):860-8.

9. Kim YH, Kim BJ, Bang KH, Hwang Y, Jang TY. Septoplasty improves life quality related to allergy in patients with septal deviation and allergic rhinitis. Otolaryngology--Head and Neck Surgery. 2011 Dec 1;145(6):910-4.

10. Beck JC, Sie KCY: The growth and development of the nasal airway. Facial Plast Surg Clin North Am 1999; 7:257.

11. Enlow DH: Facial growth, Ed 3 Philadelphia, WB Saunders, 1990.

12. Tardy MD. Rhinoplasty. The art and the science, Philadelphia, W.B. Saunders, 1997.

13. Younger RAL, Denton AB. Controversies in turbinate surgery. Facial Plast Surg Clin North Am 1999; 7:311.

14. Heinberg CE, Kern EB. The Cottle sign. An aid in the physical diagnosis of nasal airflow disturbances. Rhinology 1973; 11:89.

15. Arbour P, Kern EB. Paradoxical nasal obstruction. Can J Otolaryngol 1975; 4:333.

16. Kent SE, Reid AP, Nairn ER, Brain DJ. Neonatal septal deviations. J R Soc Med. 1988 Mar; 81(3):132-5.

17. Cole P. Acoustic rhinometry and rhinomanometry. Rhinol Suppl. 2000 Dec; 16:29-34.

18. Corey JP, Gungor A, Nelson R, Liu X, Fredberg J. Normative standards for nasal cross-sectional areas by race as measured by acoustic rhinometry. Otolaryngology Head Neck Surg. 1998 Oct; 119(4):389-93.

19. Shemen L, Hamburg R. Preoperative and postoperative nasal septal surgery assessment with acoustic rhinometry. Otolaryngol Head Neck Surg. 1997 Oct; 117(4):338-42.

20. Wei JL, Remington WJ, Sherris DA. Work-up and evaluation of patients with nasal obstruction. Facial Plast Surg Clin North Am 1999; 7:263.

21. Adams W. On the treatment of the broken nose by forcible straightening and mechanical apparatus. Br Med J. 1875 Oct $2 ; 2(770): 421-2$.

22. Asch MJ. Treatment of nasal stenosis due to deflective septum with and without thickening of the convex side. Laryngoscope $1899 ; 6: 340$.

23. Freer OT. The correction of delections of the nasal septum with minimum traumatism. Journal of the American Medical Association. 1902; 38:636.

24. Krieg R. Resection der cartilagoquadrangularis septinasemsurheilung der scoliosis septi. Medicinishes Cocrespondenz blatt Wurtenburgishen Artzlicken Verein Stuttgart 1886; 56:201.

25. Boenninghaus G. Bemerkungenzumaufsatzeloewes: zurchirurgie der nasenscheidewand. MonatsschrOhrenh 1900; 34:287.

26. Fomon S, Syracuse VR, et al. Plastic repair of the deflected nasal septum. Arch Otolaryngol. 1946 Aug; 44:14156.

27. Killian G. The submucous window resection of the nasal septum. Annals of Otology. 1905; 14: 363-7.

28. Barelli PA, Loch EE, Kern Eb, Steiner. A (Eds), Rhinology: the collected writings of Maurice H Cottle MD. Warwick, NY: American Rhinologic Society, 1987.

29. Sercer A. Die Dekortikation der Nase. In: Sercer A, Mundlich K. Plasticheoperationenan der Nase and der Ohrmuschel. Stuggart: Theime, 1962.

30. Padovan IF. External approach in rhinoplasty (decortications). In: Conley J, Dickinson JT (Eds). Plastic reconstructive surgery of the face and neck, Vol.1. Stuttgart: Theime, 1972: 143 - 6.

31. Goodman WS. External approach to rhinoplasty. Can J Otolaryngol. 1973; 2(3):207-10. 